\title{
Analisisi Perspektif Mahasiswa pada Penerapan Kertas Kerja ATLAS di Era Digital
}

\author{
Muhammad Sulaiman Sugiharto ${ }^{1}$, Kelvin Bagus Anugrah ${ }^{2 *}$, Lala Anggun Putri \\ Wandira $^{3}$, Dhika Maha Putri ${ }^{4}$ \\ 1,2,3,4 Universitas Negeri Malang, Jl. Semarang No. 5, Malang, Indonesia
}

http://

\section{Abstract}

The digital era demand that accounting students, the future of Indonesian's auditor to adapt to the rapid change of time. Thus, to improve the quality of those future auditors, the Indonesian government designed ATLAS. ATLAS was designed to digitalize and replace the old, obsolete audit working paper from the government's perspective. But what about student's perspectives of this digitalization? This research uses the Likert scale to answer that question. In addition, this research investigates student's perspectives of the implementation of ATLAS as an audit working paper. We found that $78.18 \%$ of the students have a favourable view/perspective of ATLAS implementation as an audit working paper.

\section{Type of Paper: Empirical}

Keywords: Students perspective, ATLAS, working paper, Digital era

\section{Pengantar}

Dunia sedang memasuki era digital, dimana digitalisasi telah mengubah proses dan model bisnis di berbagai aspek, termasuk aspek audit.(Manita et al., 2020). Audit memiliki peran yang signifikan dalam menunjukkan transparansi ekonomi suatu perusahaan (Kilgore et al., 2011). Kesempurnaan audit bergantung pada penerapan standar auditing yang dapat menuntun auditor secara efektif dan efisien (Kathleen Harris \& Tyler Williams, 2019), dan di Indonesia, auditor dibimbing dengan standar auditing dan kode etik yang ditetapkan Ikatan Akuntan Publik Indonesia (IAPI) (Rahmina \& Agoes, 2014).

Ikatan Akuntan Publik Indonesia (IAPI) merupakan organisasi akuntan publik yang mengatur standar auditing dan etika profesi auditor (International Federation of Accountants, 2016). Dalam menghadapi era digital, IAPI mulai menerapkan International Standard of Auditing (ISA) yang mendesak auditor untuk beradaptasi dengan standar internasional (Institut Akuntan Publik Indonesia, 2020). Karena itulah, IAPI bekerja sama dengan Pusat Pembinaan Profesi Keuangan (PPPK) dan Kementrian Keuangan dalam pembuatan program yang dapat membantu penerapan standar auditing bagi auditor, yaitu Audit Tool And Linked Archive System, atau ATLAS (Tim Penyusun ATLAS, 2019).

\footnotetext{
${ }^{*}$ Penulis yang sesuai:

E-mail: kelvinanugrah309@gmail.com

Afiliasi: Universitas Negeri Malang
} 
ATLAS merupakan program yang dirancang untuk menjalankan dan mencatat hasil audit berdasar standar yang berlaku, sebagai dasar pemberian opini (Tim Penyusun ATLAS, 2019). Dalam pembuatannya, diharapkan bahwa ATLAS akan di implementasikan pada pelaksanaan audit kedepannya, termasuk untuk generasi muda era digital, seperti mahasiswa. Mahasiswa merupakan tulang punggung perkembangan negara (Weng et al., 2021), dan karena itulah persepsi mereka terhadap teknologi yang memiliki kemampuan untuk berkontribusi pada perkembangan negara dapat dinilai signifikan.

Singkatnya, mahasiswa merupakan aset yang sangat penting bagi negara, dan karena itulah persepsi mereka begitu berpengaruh. Jadi, dibutuhkan penelitian lebih lanjut atas persepektif mahasiswa terhadap program-program yang menyangkut peningkatan kualitas audit, seperti ATLAS.

\section{Literature Review}

Demi mendukung pandangan yang kami ringkas di bagian latar belakang, kami menyusun kajian pustaka yang akan membahas konsep-konsep inti dalam penelitian ini. Di dalam kajian pustaka ini, kami membahas setiap konsep secara lebih detil, sekaligus mengungkapkan hubungan antara masing-masing konsep.

\subsection{Persepsi Mahasiswa}

Dalam membuat sebuah perencanaan yang matang mengenai suatu permasalahan, diperlukan suatu informasi. Dewasa ini, beragam jenis informasi dapat kita gunakan untuk memenuhi kebutuhan kita. Menariknya, saat ini kita diberikan kemudahhan untuk akses informasi melalui beberapa platform digital. Namun, beragamnya informasi yang tersedia pada media digital justru membuat sebagian besar orang membuat persepsi tanpa mengetahui detail informasi terlebih dahulu. Secara umum, persepsi merupakan cara pandang seseorang terhadap suatu objek (Deviyanti et al., 2017). Persepsi adalah pekerjaan pola pikir manusia setiap hari yang terkait dengan ide (Latar, n.d.). Menurut Davidoff (1981) dalam Akbar (2015), stimulus presepsi memiliki kesamaan antar individu satu dengan lainnya, tetapi pengalaman, kemampuan berpikir, dan kerangka gagasan tidak sama. Hal tersebut menyebabkan adanya kemungkinan perbedaan cara pandang (persepsi) antara individu yang satu dengan individu yang lain. Salah satu contohnya adalah persepsi mahasiswa terhadap proses auditing yang diintegrasikan dengan aplikasi digital.

Berdasarkan beberapa pendapat di atas, tentu saja persepsi dapat menjadi suatu alternatif apakah suatu keputusan dapat diimplementasikan atau tidak. Dengan demikian, dapat disimpulkan bahwa persepsi merupakan cara pandang seseorang terhadap sebuah obyek atau kejadian tertentu. Pada akhirnya, cara pandang tersebut menghasilkan sebuah penafsiran terhadap objek yang bersangkutan. Terkait dengan persepsi, Mahasiswa Fakultas Ekonomi dan Bisnis tentu nantinya juga memiliki persepsi yang berbeda terhadap suatu hal yang berkaitan dengan bidang yang dinaunginya. Persepsi yang muncul dapat berupa persepsi yang bersifat positif dan negatif.

\subsection{Standar Audit}

Salah satu hal yang sangat erat kaitannya dengan profesi auditor ialah standar audit. Standar audit merupakan sebuah pedoman bagi seorang auditor dalam melaksanakan tugas dan tanggung jawab profesionalnya (Duncan \& Whittington, 2014; Hery, 2017, p. 28; Ningsih \& Nadirsyah, 2017). Menurut Titera (2013), standar audit digunakan oleh auditor untuk melakukan analisis data dalam ranah eksternal bisnis dan menilai risiko bisnis. Sejalan dengan hal tersebut, Habib (2015) menyampaikan bahwa standar audit merupakan patokan seorang auditor dalam mengevaluasi kualitas laporan keuangan dan informasi akuntansi klien. Oleh seab itu, kepatuhan terhadap standar audit dapat mengurangi kemungkinan gap antara auditor dengan investor yang merupakan pemakai utama dari laporan keuangan perusahaan (Gao \& Zhang, 2018; Habib, 2015).

Secara umum, terdapat dua jenis audit yaitu audit eksternal dan audit intenral. Shanasirova (2018) menjelaskan bahwa kedua jenis audit tersebut memiliki standar yang 
berbeda, tetapi sama-sama bertujuan untuk mewujudkan iklim pengelolaan bisnis yang terbebas dari kecurangan. Standar audit eksternal dan internal sama-sama dapat mendukung upaya pemerintah dalam mewujudkan sistem tata kelola perusahaan yang baik (Good Corporate Governance) (Alzeban, 2019). Dalam hal ini, auditing memainkan peran yang sangat penting untuk menegakkan kepatuhan bisnis, termasuk mendeteksi kecurangan (fraud) yang dilakukan oleh orang dalam perusahaan (Habib, 2015).

Standar audit memang ditujukan untuk mewujudkan iklim bisnis yang kondusif dan tetap sehat. Namun, beberapa standar audit justru menjadi hambatan bagi seorang auditor dalam menjalankan proses pemeriksaan (Gao \& Zhang, 2018; Titera, 2013). Standar audit dapat membatasi usaha seorang auditor dalam melakukan aktivitas pemeriksaan karena sifatnya yang kaku (Alzeban, 2019). Meskipun standar audit sudah diciptakan selama bertahun-tahun dan mengalami revisi berkali-kali, pada kenyataannya masih meninggalkan beberapa sistem yang tidak sempurna (Alzeban, 2019). Dalam hal ini, dibutuhkan sebuah standar audit yang lebih fleksibel dan dapat disesuaikan dengan perkembangan zaman (Turayev \& Ochilov, 2018).

\subsection{Kertas Kerja Audit}

Standar Audit (SA) Seksi 339 menyebutkan bahwa Kertas Kerja Audit adalah catatan yang dibuat oleh auditor mengenai informasi audit yang diperoleh, pengujian yang dilakukan, prosedur audit yang ditempuh, dan simpulan yang dibuat berdasarkan proses audit. Beberapa contoh bagian dari Kertas Kerja Audit adalah: (1) surat konfirmasi; (2) program audit; (3) dokumen-dokumen perusahaan; (4) memorandum; (5) hasil analisis; dan lain sebagainya. Kertas Kerja Audit juga dapat berupa data yang disimpan dalam media elektronik seperti pita magnetik atau film. Kertas Kerja Audit terdiri dari tiga jenis, yaitu: (1) KKA Utama atau Top (2) KKA Pendukung atau Supporting Schedule (3) KKA Ikhtisar (Maisyarah, 2019). Di era digital, perkembangan teknologi informasi sendiri sudah semakin meningkat. Hal tersebut tentu saja berimbas pada proses audit yang semakin efektif dan efisien. Beberapa contoh aplikasi bidang auditing yang saat ini sudah digunakan pada beberapa negara adalah Netwrix Auditor, Cygna Auditor, iAuditor, Itelex (Louie, 2019)

Penggunaan media elektronik sebagai kertas kerja audit dapat membantu para auditor untuk mempermudah proses auditing yang dilakukannya. Salah satu manfaat yang dapat diperoleh dari penggunaan tersebut ialah waktu pengerjaan yang semakin efektif apabila dibangingkan dengan media cetak. Dengan demikian, waktu yang diperlukan untuk melaksanakan audit menjadi lebih ringkas sekaligus dapat meminimalisir risiko kesalahan yang umumnya terjadi pada pekerjaan manual. Di Indonesia, penggunaan media elektronik sebagai kertas kerja audit diimplementasikan melalui Audit Tool and Linked Archive System (ATLAS). Perangkat lunak tersebut telah dirilis oleh Kementrian Keuangan bersama Ikatan Akuntan Indonesia dalam hal auditing terhadao perusahaan berskala kecil dan menengah. DI beberapa negara, penerapan kertas kerja audit berbasis elektronik bukanlah suatu yang baru. Namun, penggunaan aplikasi ATLAS di Indonesia adalah hal baru bagi seorang auditor. Oleh sebab itu, diperlukan sebuah pengembangan dan pelatihan pengoperasiaan aplikasi ATLAS melalui pembelajaran di lingkungan mahasiswa.

\section{Metodologi Penelitian}

Penelitian ini menggunakan pendekatan kuantitatif dimana pertanyaan deskriptif digunakan oleh peneliti untuk mengidentifikasi tanggapan responden terhadap variabel yang diteliti (Creswell, 2012). Menurut Sugiyono (2010), jenis penelitian deskriptif digunakan oleh peneliti untuk mengetahui adanya variabel mandiri atau variabel yang berdiri sendiri. Adapun variabel mandiri yang menjadi objek dalam penelitian ini adalah perspektif mahasiswa terhadap penerapan Audit Tool and Linked Archive System (ATLAS) di era digital. Data penelitian diperoleh dengan cara survei menggunakan kuisioner yang disebarkan kepada responden. Instrumen penelitian berupa kuisioner menjadi pilihan karena dapat mengumpulkan data dalam jumlah yang besar (Ismail \& AlBahri, 2019).

Populasi dalam penelitian ini adalah seluruh Mahasiswa Jurusan Akuntansi Universitas Negeri Malang Angkatan 2016 hingga 2020. Hal ini dikarenakan rentang angkatan tersebut merupakan yang paling relevan dan mencerminkan kaum milenial yang sangat bergantung pada 
teknologi. Pengambilan sampel dilakukan dengan teknik purposive random sampling. Menurut Tongco (2006), teknik purposive random sampling digunakan oleh peneliti untuk menemukan responden, berapa banyak responden yang dibutuhkan, dan bagaimana analisis data dilakukan dengan andal. Adapun kriteria responden dalam penelitian ini adalah sebagai berikut:

a) Mahasiswa Jurusan Akuntansi Universitas Negeri Malang angkatan 2016 - 2020;

b) Pernah menempuh matakuliah pengauditan;

c) Pernah menggunakan kertas kerja audit.

Data hasil kuisioner yang diperoleh peneliti, dianalisis menggunakan statistik deskriptif dan diukur menggunakan Skala Likert. Skala ini digunakan untuk mengukur perspektif seseorang terhadap suatu peristiwa atau kejadian berdasarkan pertanyaan penelitian (Rahardja et al., 2018). Setiap pertanyaan diberikan skor berjenjang dimana semakin tinggi nilai, maka semakin baik persepsi responden terhadap objek yang diteliti (Kurniawan \& Puspitaningtyas, 2016). Dalam penelitian ini, peneliti memeberikan nilai 5 untuk jawaban Sangat Setuju (SS), 4 untuk jawaban Setuju (S), 3 untuk jawaban Netral (N), 2 untuk jawaban Tidak Setuju (TS), dan 1 untuk jawaban Sangat Tidak Setuju (STS).

\section{Hasil dan Diskusi}

Hasil penelitian yang peneliti lakukan didasarkan pada hasil kuesioner, dengan target responden mahasiswa yang sudah menempuh mata kuliah audit. Kuesioner terbagi menjadi 3 bagian, pertama yaitu identitas responden, kedua mengenai info seputar ATLAS dan terakhir mengenai persepsi mahasiswa.

\subsection{Skala Likert}

Skala Likert berfungsi sebagai alat untuk menghitung persepsi, opini atau pendapat responden pada suatu peristiwa berdasarkan pernyataan yang telah ditetapkan.

Tabel 1. Perhitungan nilai skala

\begin{tabular}{lc}
\hline Skala Jawaban & Nilai Skala \\
\hline Sangat Setuju (SS) & 5 \\
\hline Setuju (S) & 4 \\
\hline Netral (N) & 3 \\
\hline Tidak Setuju (TS) & 2 \\
\hline Sangat Tidak Setuju (STS) & 3 \\
\hline
\end{tabular}

\subsection{Teknik Pengolahan Kuisioner}

Setelah pernyataan telah berhasil dilakukan dengan menyebarkannya epada responden, lalu tahap berikutnya ialah mengolah kuisioner berdasarkan skala likert. Sehingga perhitungan yang dilakukan menggunakan metode skala likert bukan SPSS.

\subsection{Pengolahan Data}

Pengolahan data merupakan data dari hasil kuesioner yang dibagikan peneliti melalui medai sosial yaitu Whatsapp. Terdapat 35 responden, dengan total 175 respon. Terdapat 8 pernyataan yang terbagi menjadi 2 bagian, yaitu:

a. Bagian pengetahuan umum

Terdapat 3 pertanyaan di dalam pengetahuan umum yang direfleksikan ke dalam tabel di bawah ini. 
Muhammad Sulaiman Sugiharto, Kevin Bagus Anugrah, Lala Anggun Putri Wandira, Dhika Maha Putri

Tabel 2. Pertanyaan pengetahuan umum

\begin{tabular}{|c|c|c|}
\hline \multirow{2}{*}{\multicolumn{3}{|c|}{$\begin{array}{l}\text { Pertanyaan } \\
\text { Apakah anda sudah menempuh mata kuliah praktikum } \\
\text { audit? }\end{array}$}} \\
\hline & & \\
\hline Apakah anda pernah mengisi kertas kerja audit? & & \\
\hline $\begin{array}{l}\text { Pernahkah anda mendengar tentang program kertas kerja } \\
\text { audit ATLAS? }\end{array}$ & & \\
\hline
\end{tabular}

b. Bagian persepsi mahasiswa

Terdapat 5 pernyataan pada bagian presepsi mahasiswa yang direfleksikan ke dalam tabel di bawah ini.

Tabel 3. Pernyataan perspektif mahasiswa

\begin{tabular}{|c|c|c|c|c|c|}
\hline Pernyataan & SS & $S$ & $\mathrm{~N}$ & TS & STS \\
\hline $\begin{array}{l}\text { Menurut saya, ATLAS dapat memudahkan } \\
\text { pekerjaan auditor. }\end{array}$ & & & & & \\
\hline $\begin{array}{l}\text { Saya setuju bila ATLAS di implementasikan di } \\
\text { Indonesia. }\end{array}$ & & & & & \\
\hline $\begin{array}{l}\text { Menurut saya, ATLAS dapat menggantikan kertas } \\
\text { kerja audit manual. }\end{array}$ & & & & & \\
\hline $\begin{array}{l}\text { Menurut saya, ATLAS akan cocok untuk diajarkan } \\
\text { kepada mahasiswa yang menempuh mata kuliah } \\
\text { Audit. }\end{array}$ & & & & & \\
\hline $\begin{array}{l}\text { Saya bersedia untuk menggunakan ATLAS sebagai } \\
\text { kertas kerja audit }\end{array}$ & & & & & \\
\hline
\end{tabular}

\subsection{Interpretasi untuk Skor Perhitungan}

$\mathrm{Y}=$ skala tertinggi yang terdapat pada likert $\mathrm{x}$ jumlah seluruh responden

$\mathrm{X}=$ skala terendah yang terdapat pada likert $\mathrm{x}$ jumlah seluruh responden

Jumlah skala tertinggi untuk item "Sangat Setuju" adalah 5 x $175=875$, sedangkan skala terendah untuk item "Sangat Tidak Setuju" adalah 1 x $175=175$

\subsection{Rumus Index \% = Total Skor $/ Y \times 100$}

Setelah nilai Y diketahui, maka dilakukan perhitungan menggunakan rumus index untuk mengetahui interval dan interpretasi persen agar peneliti mengetahui penilaian dengan metode mencari Interval skor persen (I). Rumus index dijabarkan pada setiap bagian pernyataan kuesioner.

\subsection{Rumus Interval}

I = $100:$ Jumlah Skor (Skala Likert)

Maka $=\frac{100}{5}=20$

Hasil $(\mathrm{I})=20$ (hasil interval jarak dari terendah 0\% hingga tertinggi 100\%)

Berikut adalah kriteria interpretasi skornya berdasarkan interval :
a. $80 \%-100 \%$
b. $60 \%-79,99 \%$
$=$ Sangat Setuju.
c. $40 \%-59,99 \%=$ Netral.
d. $20 \%-39,99 \%=$ Tidak Setuju. 
Muhammad Sulaiman Sugiharto, Kevin Bagus Anugrah, Lala Anggun Putri Wandira, Dhika Maha Putri

e. $0 \%-19,99 \%=$ Sangat Tidak Setuju

\subsection{Pengolahan Data Setiap Bagian Kuisioner}

Hasil dari kuisioner mengenai persepsi mahasiswa terdapat 5 pernyataan, keseluruhan bagian ini berhasil mengumpulkan 35 responden. Sehingga keseluruhan respon ialah 175. Terdapat 28 respon SS, 105 respon S, 40 respon N, 2 respon TS, dan 0 respon STS.

\subsubsection{Rumus T x Pn}

Tabel 4. Pengolahan kuisioner bagian persepsi mahasiswa

\begin{tabular}{lcc}
\hline Jawaban & T x Pn & Jumlah \\
\hline Sangat Setuju & $28 \times 5$ & 140 \\
\hline Setuju & $105 \times 4$ & 420 \\
\hline Netral & $40 \times 3$ & 120 \\
\hline Tidak Setuju & $2 \times 2$ & 4 \\
\hline Sangat Tidak Setuju & $0 \times 1$ & 0 \\
\hline
\end{tabular}

Keterangan :

T : Jumlah responden yang memilih

Pn : Skor angka likert

\subsubsection{Perhitungan Akhir}

Dari jumlah pengolahan kuisioner diatas maka diperoleh total perhitungan sebagai berikut: $(140+420+120+4+0=684)$.

Rumus Index $100 \%=\frac{\text { Total Skor }}{(Y \times 100 \%)}$

$$
\begin{aligned}
& =\frac{684}{(875 \times 100 \%)} \\
& =78.17 \%
\end{aligned}
$$

Berdasarkan perhitungan tersebut, didapatkan bahwa $78.17 \%$ mahasiswa tergolong interval "setuju", atau memiliki persepektif positif pada implementasi ATLAS sebagai kertas kerja audit.

\section{Kesimpulan}

Penelitian ini bertujuan untuk mengukur persepsi mahasiswa akuntansi terhadap implementasi Audit Tool and Linked Archive System (ATLAS) di era digital. Pendekatan pada penelitian ini adalah deskriptif kuantitatif, dimana peneliti menggunakan alat ukur berupa Skala Likert dalam mengukur persepsi dan opini mahasiswa. Hasil penelitian menunjukkan bahwa mahasiswa di era disrupsi teknologi setuju untuk mengimplementasikan ATLAS sebagai kertas kerja audit secara universal di masa mendatang. Hal ini dikarenakan ATLAS dapat memudahkan para pengguna (auditor) dalam melakukan pekerjaannya.

Hasil penelitian ini diharapkan menjadi pertimbangan bagi pemerintah, khususnya Kementrian Pendidikan, untuk segera mengintegrasikan ATLAS dengan kurikulum pendidikan dalam bidang akuntansi dan auditing. Keterbatasan dari penelitian ini ialah penggunaan metode skala rikert yang hanya mampu mengukur presepsi responden serta jumlah sampel yang masih sangat sedikit. Oleh sebab itu, penelitian selanjutnya diharapkan dapat melengkapi keterbatasan dari penelitian ini dengan menggunakan metode yang berbeda serta memperluas jangkauan sampel. 
Muhammad Sulaiman Sugiharto, Kevin Bagus Anugrah, Lala Anggun Putri Wandira, Dhika Maha Putri

\section{Daftar Pustaka}

Akbar, R. F. (2015). Analisis Persepsi Pelajar Tingkat Menengah Pada Sekolah Tinggi Agama Islam Negeri Kudus. Edukasia: Jurnal Penelitian Pendidikan Islam, 10(1), 189-210. https://doi.org/10.21043/edukasia.v10i1.791

Alzeban, A. (2019). An examination of the impact of compliance with internal audit standards on financial reporting quality: Evidence from Saudi Arabia. Journal of Financial Reporting and Accounting, 17(3), 498-518. https://doi.org/10.1108/JFRA-09-2018-0085

Creswell, J. W. (2012). Educational Research: Planning, Conducting, and Evaluating Quantitative and Qualitative Research.

Deviyanti, L. P., Purnamawati, I. G. A., Eka, utu A., \& Yasa, 2I Nyoman Putra. (2017). SAHAM DI PASAR MODAL ( Studi Pada Mahasiswa Jurusan Akuntansi Program S1 Universitas Pendidikan Ganesha). 1(1).

Duncan, B., \& Whittington, M. (2014). Compliance with standards, assurance and audit: Does this equal security? ACM International Conference Proceeding Series, 77-84. https://doi.org/10.1145/2659651.2659711

Gao, P., \& Zhang, G. (2018). Auditing Standards, Professional Judgment, and Audit Quality. Journal of International Accounting Research, 90(4), 1395-1435.

Habib, A. (2015). The new Chinese accounting standards and audit report lag. International Journal of Auditing, 19(1), 1-14. https://doi.org/10.1111/ijau.12030

Hery. (2017). Auditing dan Asurans: Pemeriksaan Akuntansi Berbasis Standar Audit Internasional (Adipramono (ed.)). PT Grasindo.

Institut Akuntan Publik Indonesia. (2020). Penerapan SA Berbasis ISA Secara Proposional Sesuai Ukuran dan Kompleksitas Suatu Entitas. 1-180.

Ismail, I., \& AlBahri, F. P. (2019). Perancangan E-Kuisioner menggunakan CodeIgniter dan React-Js sebagai Tools Pendukung Penelitian. Jurnal Sains Komputer Dan Informatika, 3(2), 337-347. https://doi.org/10.30645/j-sakti.v3i2.152

Kathleen Harris, M., \& Tyler Williams, L. (2019). Evidence-based policymaking in auditing regulation: An historical analysis of academic research citation in PCAOB standard-setting practices. Journal of Accounting and Public Policy, 38(3), 238-251. https://doi.org/10.1016/j.jaccpubpol.2019.05.003

Kilgore, A., Radich, R., \& Harrison, G. (2011). The Relative Importance of Audit Quality Attributes. Australian Accounting Review, 21(3), 253-265. https://doi.org/10.1111/j.18352561.2011.00141.X

Kurniawan, A. W., \& Puspitaningtyas, Z. (2016). Metode Penelitian Kuantitatif (1st ed.). PAVINDA BUKU.

Latar, A. (n.d.). Persepsi Mahasiswa Akuntansi tentang Independensi.

Louie, A. (2019). Best Auditing Software for 2020. Financesonline. https://financesonline.com/bestauditing-\%0Asoftware/

Manita, R., Elommal, N., Baudier, P., \& Hikkerova, L. (2020). The digital transformation of external audit and its impact on corporate governance. Technological Forecasting and Social Change, 150(September 2019), 119751. https://doi.org/10.1016/j.techfore.2019.119751

Ningsih, F., \& Nadirsyah. (2017). Pengaruh Independensi, Skeptisisme Profesional Auditor, Penerapan Standar Audit, dan Etika Audit Terhadap Kualitas Hasil Audit (Studi Pada Auditor BPK RI Perwakilan Provinsi Aceh). Jurnal Ilmiah Mahasiswa Ekonomi Akuntansi, 2(3), 48-58.

Rahardja, U., Lutfiani, N., \& Rahmawati, R. (2018). Persepsi Mahasiswa Terhadap Berita Pada Website $\begin{array}{llll}\text { APTISI. Jurnal Ilmiah SISFOTENIKA, } & \text { 8(2), }\end{array}$ http://sisfotenika.stmikpontianak.ac.id/index.php/ST/article/view/400

Rahmina, L. Y., \& Agoes, S. (2014). Influence of Auditor Independence, Audit Tenure, and Audit Fee on Audit Quality of Members of Capital Market Accountant Forum in Indonesia. Procedia - Social and Behavioral Sciences, 164(August), 324-331. https://doi.org/10.1016/j.sbspro.2014.11.083

Shanasirova, N. (2018). The Issues of Organizing Internal Audit. International Finance and Accounting, 4. https://uzjournals.edu.uz/interfinance/vol2018/iss4/34

Sugiyono. (2010). Metode Penelitian Kuantitatif dan Kualitatif dan R\&D. ALFABETA.

Tim Penyusun ATLAS. (2019). Buku Panduan Penggunaan Aplikasi ATLAS (Audit Tools and Linked Archieve System).

Titera, W. R. (2013). Updating audit standard-enabling audit data analysis. Journal of Information Systems, 27(1), 325-331. https://doi.org/10.2308/isys-50427 
Muhammad Sulaiman Sugiharto, Kevin Bagus Anugrah, Lala Anggun Putri Wandira, Dhika Maha Putri

Tongco, M. D. C. (2006). Purposive Sampling as a Tool for Informant Selection. A Journal of Plants, People, and Applied Ressearch, 5, 147-158.

Turayev, A., \& Ochilov, O. (2018). Internal Audit Is a Form of the State Financial Control: National and International Features. International Finance and Accounting, 2018(4). https://uzjournals.edu.uz/interfinance/vol2018/iss4/5

Weng, X., Qi, L., \& Tang, P. (2021). Research on college students' physical exercise trend based on compartment model. Mathematics and Computers in Simulation, 180, 24-42. https://doi.org/10.1016/j.matcom.2020.08.016 